Отримано: 20 серпня 2021 року

Прорецензовано: 6 вересня 2021 року

Прийнято до друку: 20 вересня 2021 року

e-mail: oleeesya@yahoo.com

DOI: $10.25264 / 2519-2558-2021-11(79)-120-123$
Dobosh O. S., Saban O. V. The archetypal symbols of Light and Darkness in the Brexit saga. Наукові записки Наиіонального університету "Острозька академія»: серія "Філологія». Острог : Вид-во НаУОА, 2021. Вип. 11(79). С. 120-123.

\author{
Oksana Dobosh, \\ English Lecturer, \\ Lviv Plytechnic National University \\ Olesia Saban, \\ English Lecturer \\ Lviv Plytechnic National University
}

UDC: 811.111'27'42-11:[327:007](410:4-672CC)"20"

\title{
THE ARCHETYPAL SYMBOLS OF LIGHT AND DARKNESS IN THE BREXIT SAGA
}

The article deals with the analysis of concepts of natural phenomena which are employed to verbalize the concept of Brexit from the perspective of cognitive linguistics. The research is performed using different approaches: from etymological origin to functional dynamics. For this purpose the archetypal symbols of Light and Darkness are chosen. The study is based on the online resources of modern English language media, covering the issues related to politics and economy. Correspondingly, the aspects of the concept of Brexit which are illustrated through the prism of archetypal symbols and are consequentially analyzed scrutinize the consequences of the Brexit transition period. As a matter of fact, the archetypal symbols of Light and Darkness are referred to so as to determine the characteristic features of the emotional, epistemological, ethical, religious and ontological aspects of the withdrawal of Great Britain from the European Union. The ensuing issues of this complicated process are also elucidated. Their etymological specificity and semantic functions are analyzed along with the description of their distinguishing characteristics. It has been established that the archetypal symbols under consideration are not mutually exclusive, but on the contrary are closely intertwined and complementary, thus giving a more vivid, complete and understandable description of multiple aspects of Brexit.

Key words: archetype, Brexit, discourse, concept, natural phenomena, symbol.

\section{Добош Оксана Степанівна,} асистент,

Національний університет «Львівська політехніка»

\section{Сабан Олеся Василівна,}

асистент,

Національний університет «Львівська політехніка»

\section{АРХЕТИПНІ СИМВОЛИ «СВІТЛО» ТА «ТЕМРЯВА» САГИ ПРО «БРЕКЗИТ»}

У статті розглянуто архетипні символи «світло» та «темрява» по відношенню до концепту «Брекзит», на основі прикладів їхнього вживання у ресурсах економічного та політичного спрямування сучасних англомовних онлайн медіа, зокрема, крізь призму когнітивної лінгвістики. Виокремлено аспекти концепту «Брекзит», з якими асочіюються ияі символи, а саме: емотивний, епістеміологічний, етичний, релігійний та онтологічний. Також описано конотації та субсимволи. Проаналізовано їхню етимологічну специфіку та семантичні функиії, а також визначено їхні характерні риси. Встановлено, ще досліджувані символи не є взаємовиключними, а навпаки тісно переплітаються та взаємодоповнюють один одного, даючи більш виразну, повну та зрозумілу характеристику окремим аспектам Брекзиту.

Ключові слова: архетип, “Брекзит”, дискурс, концепт, природні стихї, символ.

Introduction: The images of basic natural phenomena, such as Light and Darkness, have been the object of a number of linguistic studies conducted so far by both foreign and Ukrainian scholars. Understanding of the world through the prism of Light and Darkness (empirical - epistemological - emotional - evaluative aspects) is related to the development of symbolic meanings. By bringing the evaluative aspect to the fore, we extend all symbolic meanings of concepts, which gives rise to new facets of the symbols (ethical, religious, ontological, etc.). Thus, the axiological metaphor Light-Darkness reflects the most important feature of human consciousness, i.e. the subjective perception of the phenomena of reality in terms of their positive and negative qualities. Taking into account the above-mentioned considerations and having thoroughly analysed theoretical background to the natural phenomena imagery, conceptualization and symbolism, the study of individual representations of images, archetypal symbols or concepts of natural phenomena in relation to the concept of Brexit is considered to be relevant.

The aim of the article is to discover, analyse, highlight and reach the understanding of specific features of the concepts of Light and Darkness dichotomy in relation to the concept of Brexit in modern English economic and political discourse.

Publications overview: The archetypal symbols of Light and Darkness are generally interpreted in humanities as a dyad or as a means of primitive understanding of the world. In philosophy, for instance, Light and Darkness are perceived as a condition and a primary cause of being (Light) and a prereproduction state, chaos (Darkness) (P. Florensky); as a symbol of beauty, joy, purity, holiness, goodness and, respectively, as a symbol of ugliness, grief, immorality, evil (A. Potebnia, B. Soloviev); as a source of knowledge, enlightenment and, respectively, ignorance, cultural backwardness (A. Losev, M. Mamardashvili). In linguistics, the linguistic means denoting the phenomena of light and darkness are subjects of major interest, since we tend to theorize on the processes of conceptualization largely proceeding from the system of linguistic representations of knowledge (H. Boldyrev, G. Tokarev).

Statement of the problem: Despite the fact that the lexical and semantic field of light and darkness is one of the most meaningfully analysed and widely interpreted, the linguistic aspect of these concepts in respect of Brexit has not been thoroughly investigated yet. 
Hence, the scientific novelty of the research is that it presents a comprehensive study of the concept of Brexit through the prism of the archetypal symbols of Light and Darkness and a number of subsymbols.

Research materials: The study is based on the articles and resources of modern English language media, covering the political and economic issues related to Brexit.

Methodology: The research in the given piece is based on relevant works of renowned linguists, presenting theoretical background, as well as heterogeneous, structurally semantic material. The analysis of the archetypal symbols found in the articles on Brexit is carried out from the perspective of cognitive linguistics and is performed using different approaches from etymological origin to functional dynamics.

Research and discussion: The term "archetype" means original pattern in ancient Greek. I. Protsyk proposes the definition of the archetype as a kind of matrix that reveals the archaic views of the world and the place of the individual in it. The determinant of such a matrix, according to the researcher, is the image, deeply symbolic or metaphorical due to the close connection with the semantic fields of other images [2, p. 15].

L. Shevchenko defines symbol as archetypal because it models and translates the memory of civilization [5, p.16]. Symbolic meaning transmits knowledge about the set of existential realities, mentally representing them in the mind of the individual. As C. Jung noted, the symbol synthesizes the conscious and the subconscious, the rational and the irrational, a thought and a feeling, perception and intuition [3, p. 146].

According to Merriam-Webster dictionary the nouns Light and Darkness have more than one denotative meaning. Admittedly, it is essential to enlist the most frequently cited entries of those words because it will shed light upon the ensuing multiple connotative meanings of both lexemes. Light (n): 1) something that makes vision possible: artificial light, celestial body; electric light; 2) daylight, dawn; 3) spiritual illumination, enlightenment, truth [20]. Darkness: 1) the total or near total absence of light the quality of being dark in shade or colour; 2) a gloomy or depressed state or tone; 3) a lack of knowledge or enlightenment; 4) evil [14]. Evidently, the concepts of Light and Darkness constitute a culturally significant axiological metaphorical opposition, which underlies the interpretation of various spheres of human life which have already been mentioned above and are further discussed in detail in relation to the current study.

\section{Emotional:}

- Light being a symbol of joy, happiness, love, hope, expectation is expressed by such idioms as "glimmer of hope", "points of light", "a beacon of justice", and "chunk of light" [1].

International news media sources tend to identify Brexit as a conundrum which puts UK prosperity and sustainability in jeopardy: "But when peering through the fog to try to work out just how those dangers might play out, it's as well important to keep an eye on possible points of light, too" [31].

LEDs (Sep 19, 2017) argued: "Brexit could deliver the UK industry one possible "small chunk of light" if new British laws help close loopholes in lighting industry." The lexeme "chunk" is a vivid example of lexical ambiguity which undoubtedly manifests irony in regards with the government's endeavours to mitigate the risks that Brexit might entail [18].

Despite Brexit perturbations, Ireland's EU Commissioner stated that there was a "glimmer of hope" that a deal on Brexit could still be done. Meanwhile, phraseological collocations "a glimmer of hope" or "a ray of hope" are merely a vague message that a bleak future lies ahead of the country [22].

The Guardian (Sep16, 2020) highlights that Brexit expectations went largely unmet: "Brexit Britain: from beacon of justice to law-breaking state" [8]. It is worth noting that although the original phraseological collocation "beacon of hope" underwent certain alterations and developed into "beacon of justice", "beacon of democracy" but it still preserved the meaning of hope for justice and democracy responsively.

- Darkness being a symbol of sadness, grief, misfortune, unreliability is represented by the binomial term "doom and gloom" [1].

"Vox Pop: Is there light in the darkness of Brexit? The future's bright. Or is it? Doom and gloom has spread across the media industry ..." The binomial term "doom and gloom", as cited in Merriam-Webster dictionary, means sad and tragic events; despondency. Indeed, that long headline inflicts the feeling that things are only getting worse and spirits of citizens are getting low [29].

\section{Epistemological:}

- Light as a symbol of knowledge, truth, teaching, clarity, intelligence, wisdom, and is represented by the metaphor "to light a candle", "to show a glimmer of (Brexit) sense" [1].

The Hampshire Chronicle (Jan 31, 2020) in the article "Better to light a candle than to curse the darkness" cites the group who gathered to hold vigil as Brexit looms. The group have joined others round the country in shining a light "symbolising the freedoms and protections they fight for and their pledge to unlock their future from Brexit's toxic legacy". In the darkness that is Brexit: "We are not here to curse the darkness, but to light a candle that can guide us through that darkness to a safe and sane future" [7].

"It is better to light a candle than curse the darkness" is a Chinese adage which means that it is better to try and tackle a problem rather than merely complain about it. Furthermore, a candle symbolizes a small response to a big problem, but it is worth taking at least a step in the right direction, instead of just bemoaning the problem (of darkness). Although candles here act as light which might enlighten those who hold them, nurture confidence and produce tranquillity, everybody should bear in mind that candle is light without heat.

"Britain shows only a glimmer of Brexit sense", as states the Financial Times (Aug 15,2017) and proceeds further on scathingly criticizing T. May's government which "has handled the Brexit negotiations with the EU so shambolically that even the slightest sign of common sense feels like a breakthrough" [10]. This headline exemplifies decomposition of set expressions by substitution and prolongation. It is considered to be a very effective stylistic device which consists in the intentional violation of the traditional norms of the use of set phrases to create a humorous, ironic, sarcastic effect or even absurdity.

- Darkness as a symbol of ignorance, misunderstanding, obscurity, stupidity, mystery, uncertainty manifests itself in the phraseological collocations "a dark cloud of uncertainty" and idioms "to be in the dark", "to cast a shadow/cloud over something", "a leap in the dark", "twilight zone" [1]. 
The title of the article "Brexit: a dark cloud of uncertainty or a time to be greedy when others are fearful?" relates to the Warren Buffet's often quoted successful strategy of "being fearful when others are greedy and greedy when others are fearful" [15]. His motto proved to be an invaluable piece of advice for those who are desperate and dejected.

"Investors are still in dark about being stripped of protections post-Brexit" (Citywire, Dec 14, 2020) [17]. The idiom "in the dark" relates to grim or depressing circumstances, whereas "to be in the dark" means to be in a state of ignorance, uninformed. "Investors who have ploughed billions of pounds into EU funds are still unaware whether they will be stripped of their consumer protections in January" [17].

Shadows, as described in The Book of Symbols, are not merely the result of obstructions to the passage of light, but rather dark entities with a nature all their own [26]. Thus, reading the headline which says: "Brexit casts long shadow over UK markets" [11], the idiom "to cast a long shadow over something" is interpreted by a reader as to have a detrimental impact on something over the long span of time.

Precariousness of UK's further contribution to EU science can play havoc with research networks in case the United Kingdom exits the European Union. All those reasonable concerns of London protesters on the deplorable state of science were voiced in the "Brexit shadow hangs over EU partnerships" article [24].

The Financial Times worn that "Boris Johnson's Brexit deal is a leap in the dark" because it is obviously a leap into the unknown, which can be done only by someone with no previous experience in that activity or little knowledge of it [12].

On January 31, 2020 Reuters officially concluded that Britain quitting EU, "stepped into transition twilight zone" which was literally moving into the no man's land of a transition period. The dictionary definition of the term "twilight zone" is a situation or conceptual area that is characterized by being undefined, intermediate, or mysterious [11].

3. Ethical:

- Light as a symbol of goodness, morality, decency, purity has a synonym bonfire [1].

Merriam-Webster Dictionary provides a deep insight into the etymology of the word "bonfire". In French, bon means "good", which has led some to believe that it is the first element of the English word bonfire - after all, a bonfire is a really good fire. British lexicographer Samuel Johnson also offered up that etymology in his 1755 Dictionary of the English Language, in which he defined bonfire as "a fire made for some public cause of triumph or exaltation." Noah Webster believed the same. However, the etymology was corrected in the 1890 Webster's International Dictionary. The word is actually derived from Middle English "bonefire", meaning literally "a fire of bones" [30]. The widely acknowledged symbolic meaning of the bonfire is that of bringing rebirth. By burning the bone, which is considered to be a form, one liberates the spirit. It is a vivid example of form and function encapsulated in a sole structure. Thus, when Boris Johnson orders "a bonfire of red tape" to give small firms a bigger slice of Government contracts after Brexit; he truly believes that it will help reignite economic growth [19]. Here a reader learns about the symbolic meaning of fire, bonfires, purification by flame and they will likely connote the phrase "a bonfire of red tape" with the radical but sure way of cleansing the rotten bureaucratic system of the UK.

- Darkness is a symbol of evil, immorality, meanness and is represented by the phrase "dark money" [1].

"The Brexit process is in chaos, and citizens across the UK still aren't allowed to know who bankrolls the politicians deciding the country's future," claims Crowdfunder in its article "Expose the dark money driving Brexit" [16]. "Dark money" refers to spending meant to influence political outcomes where the source of the money is not disclosed. Indisputably, Dark money spreads sophisticated propaganda via social media feeds worldwide.

\section{Religious:}

- Light is a symbol of God, divine, saint, faith, glory, and is expressed by the synonym afterglow [1].

Characterizing archetypal symbols, Philip Wheelwright argues that light connotes power and power is God $<\ldots>[4$, p. 105].

Merriam-Webster provides two meanings of the noun "afterglow." The literal meaning of it is a glowing light remaining in the sky after the sun has set, whereas the figurative: a happy feeling that remains after a successful or emotional event [6]. Juxtaposing the two recent years of $\mathrm{B}$. Johnson`s running the office, the $D W$ highlights the striking difference between the 2020 horrible year for the PM and the 2019, when "he was still basking in the afterglow of a comprehensive general election victory" [23]. Undoubtedly, a reader will refer to the figurative interpretation of the lexeme "afterglow" and might also connote it with the set expression "glow of God", which means "the strong, bright light of Christ which shines forth from our face due to the heart that is greatly fired up by the Holy Spirit" [21]. It is worth noting that so far B. Johnson is walking a fine line between being victorious and arrogant or hubristic which is frowned upon by the deities and maybe he will succeed to avoid the wrath of God and to lead his people to the Promised Land.

- Darkness is a symbol of dark, devilish forces, unbelief [1].

Darkness encompasses chaos; it is largely associated with demise and demolition, confinement and spiritual darkness. According to the Book of Revelation, darkness is related to "end times", and the Prince of Darkness is the devil. To minimise the impacts of Brexit on food supplies Britain's major supermarkets should "shine a light on their food security as Brexit darkness gathers" [25]. Brexit darkness is viewed as the evil forces which should be combated or the unfavourable conditions which should be withstood.

5. Ontological:

- Light is a symbol of birth, life, rebirth, beginning, and is exemplified by such expression as "new dawn" [1].

The BBC (Jan 31, 2020) pins hope on PM B. Johnson who promises "new dawn" [9] when UK leaves EU. The "new dawn" is interpreted as the beginning of new era in Merriam-Webster dictionary.

- Darkness as a symbol of dying, death, end is denotation of sunset. It is represented by idiom "false dawn" and the set expression "sunset clause" [1].

Contrary to the above statement, the RTE does not sound that optimistic in their headline: "Brexit talks: Glimmer of light or false dawn?" [13] The idiom "false dawn" means a promising situation which comes to nothing. Thus RTE scuppers British hope for the positive outcome of the EU-UK negotiation.

In the article "Sunset clause offer in Brexit powers row" (BBC, March 16 2018), Nicola Sturgeon and Carwyn Jones hope the "sunset clause" proposal could end the deadlock with the UK government [28]. According to Collins dictionary, a "sunset clause" is a provision of a law that it will automatically be terminated after a fixed period unless it is extended by law [27]. 
Conclusions and research prospects: Understandably, light and darkness are two sides of the same coin, therefore, categorical judgments regarding the fact that light is exclusively something positive and carrying hope, and darkness is hopelessness, is unacceptable. The analysis has demonstrated that Light and Darkness are perceived as meaningful space consisting of intersecting semantic sections, which include two spheres: the sphere of Light and the sphere of Darkness, which, although being qualitatively and quantitatively different constitute a single axiological metaphor in the cognitive mechanism of world perception and prove to be a British media's "measure of reality".

Taking into account the ever-changing nature of the world around us depending on the situation (political, economic, religious, cultural, environmental, etc.), the archetypal symbols are used over and over again to shape the meaning of or interpret new phenomena. Being universally known and popular with all generations, these are a good object for further study and analysis.

\section{References:}

1. Веденеева Т., Власов В. Энциклопедия мифологии. URL: http://godsbay.ru/vikings/norse_goddesses.html.

2. Процик I. В. Архетипи в художньому моделюванні світу I. Драча і М. Ореста : автореф. дис. ... канд. філ. наук : спец. 10.02 .01$. Запоріжжя, 2012. 198 с.

3. Сендерович С. Ревизия юнговой теории архетипа. Київ: Логос, 1995. С. 144-164.

4. Уилрайт Ф. Метафора и реальность. Теория метафоры: сб. / общ. ред. Н. Д. Арутюновой и М. А. Журинской. Москва : Прогресс, 1990. С. $82-110$. $478 \mathrm{c}$.

6. Afterglow. Merriam-Webster dictionary. URL: https://www.merriam-webster.com/dictionary/afterglow.

7. Better to light a candle than to curse the darkness. The Hampshire Chronicle. 2020. URL: https://www.hampshirechronicle.co.uk.

8. Brexit Britain: from beacon of justice to law-breaking state. The Guardian. 2020. URL: https://www.theguardian.com/politics/2020/ sep/16/brexit-britain-from-beacon-of-justice-to-law-breaking-state.

9. Brexit: UK to quit EU at 23:00 GMT, as PM promises 'new dawn'. BBC. 2020. URL: https://www.bbc.com/news/uk-politics-51315772.

10. Britain shows only a glimmer of Brexit sense. Financial Times. 2017. URL: https://www.ft.com/content/5ddea020-81cf-11e7-a4ce$15 \mathrm{~b} 2513 \mathrm{cb} 3 \mathrm{ff}$.

11. Carvalho R., Wilkes T. Brexit casts long shadow over UK markets. Reuters. 2020. URL: https://www.reuters.com/article/uk-britaineu-markets-graphic-idUSKBN28023K.

12. Cavendish C. Boris Johnson's Brexit deal is a leap in the dark. Financial Times. 2019. URL: https://www.ft.com/content/a5c481a0f17d-11e9-ad1e-4367d8281195.

13. Connelly T. Brexit talks: Glimmer of light, or false dawn? RTE. 2020. URL: https://www.rte.ie/news/analysis-andcomment/2020/1010/1170611-tony-connelly-brexit-analysis/.

14. Darkness. Merriam-Webster dictionary. URL:: https://www.merriam-webster.com/dictionary/darkness.

15. Eaton D. Brexit: a dark cloud of uncertainty or a time to be greedy when others are fearful? Michael Page. URL: https://www. michaelpage.co.uk/our-expertise/finance/brexit-uncertainty-or-time-be-greedy.

16. Expose the dark money driving Brexit. Crowdfunder. URL: https://www.crowdfunder.co.uk/expose-the-dark-money-driving-brexit.

17. Gyftopoulou L. Investors still in dark about being stripped of protections post-Brexit. New Model Adviser. 2020. URL: https:// citywire.co.uk/new-model-adviser/news/investors-still-in-dark-about-being-stripped-of-protections-post-brexit/a1438859.

18. Halper M. Will the real Brexit please step forward? LEDs. 2017. URL: https://www.ledsmagazine.com/leds-ssl-design/ article/16695607/will-the-real-brexit-please-step-forward-magazine.

19. Hope C. Boris Johnson orders a 'bonfire' of red tape to give small firms a bigger slice of Government contracts after Brexit. The Telegraph. 2019. URL: https://www.telegraph.co.uk/politics/2019/11/04/boris-johnson-orders-bonfire-red-tape-give-small-firms-bigger/.

20. Light. Merriam-Webster dictionary. URL: https://www.merriam-webster.com/dictionary/light.

21. Lim L. The Glow Of God. Evangel Tabernacle. 2010. URL: https://www.evangel.org.ph/the-glow-of-god/.

22. Mccarthaigh S. Brexit: 'Glimmer of hope' that a deal can still be done. Irish Examiner. 2020. URL: https://www.irishexaminer.com/ news/arid-40187985.html.

23. Mudge R. Opinion: Boris Johnson's horrible year. DW. 2020. URL: https://www.dw.com/en/opinion-boris-johnsons-horribleyear/a-56016655.

24. Peplow M. Brexit shadow hangs over EU partnerships. Nature. 2019. URL: https://www.nature.com/articles/d41586-019-03543-y.

25. Perkins C. We must shine a light on our food security as Brexit darkness gathers. The Grocer. 2017. URL: https://www.thegrocer. co.uk/the-grocer-blog-daily-bread/we-must-shine-a-light-on-our-food-security-as-brexit-darkness-gathers/558503.article.

26. Ronnberg A., Martin K. The Book of Symbols. Reflections on Archetypal Images. Köln : Taschen, 2010. 807 c.

27. Sunset clause. Collins dictionary. URL: https://www.collinsdictionary.com/dictionary/english/sunset-clause.

28. 'Sunset clause' offer in Brexit powers row. BBC. 2018. URL: https://www.bbc.com/news/uk-scotland-scotland-politics-43428824.

29. Taylor N. Vox Pop: Is there light in the darkness of Brexit? The Drum. 2016. URL: https://www.thedrum.com/opinion/2016/07/08/ vox-pop-there-light-darkness-brexit.

30. The Secret History of 'Bonfire'. Merriam-Webster dictionary. URL: https://www.merriam-webster.com/words-at-play/the-secrethistory-of-bonfire.

31. Wright M. A soft Brexit could offer opportunities, particularly for home-grown energy. Reuters Events. 2016. URL: https://www. reutersevents.com/sustainability/issue-2-points-light-dark-fog-around-brexit. 